\title{
Knowledge, attitude and willingness to donate organ among medical students of Jimma University, Jimma Ethiopia: cross- sectional study
}

Fantu Kerga Dibaba ${ }^{1 *}$,, Kabaye Kumela Goro ${ }^{1}$, Amare Desalegn Wolide², Fanta Gashe Fufa', Aster Wakjira Garedow ${ }^{1}$, Birtukan Edilu Tufa ${ }^{3}$ and Eshetu Mulisa Bobasa ${ }^{1}$

\begin{abstract}
Background: The lack of organ donors has become a limiting factor for the development of organ transplantation programs. Many countries are currently facing a severe shortage of organs for transplantation. Medical students, as future doctors can engage in the role of promoting organ donation by creating awareness and motivating the community to donate their organs besides their voluntary organ donation. The aim of this study is to assess the knowledge, attitude and willingness of undergraduate medical students' towards organ donation at Jimma University.

Methods: A cross-sectional study was conducted among 320 medical students from year I to internship using questionnaire in order to assess their knowledge, attitude and willingness regarding organ donation. Data collected was entered using epidata and analyzed using Statistical Package for Social Sciences (SPSS) software version 20.

Results: Mean ( $\pm S D$ = standard deviation) age of participants was $23.48 \pm 17.025$ years. $57.8 \%$ of the study subjects were male. There was a statistically significant interaction effect between gender and year of study on the combined knowledge questions (dependent variables) $F(25,062)=1.755, P=0.014$, Wilk's $\Lambda=.033$. Variables which were related to a positive attitude towards organ donation were: being of the male sex (Odds Ratio $=1.156$ ); having awareness about organ donation (Odds Ratio $=2.602$ ); not having a belief on the importance of burying intact body (Odds Ratio = 5.434); willingness to donate blood (Odds Ratio = 4.813); and willingness to donate organ (Odds Ratio $=19.424$ ).
\end{abstract}

Conclusion: High level of knowledge but low level of positive attitude and willingness was noticed among the study participants toward organ donation.

Keywords: Organ donation, Knowledge, Attitude, Willingness, Medical students

\section{Background}

The need for organ donation has increased globally in the past years due to an increase in organ failure [1]. Every day in the United States of America (USA), 21 people die waiting for an organ and more than 120,048

\footnotetext{
* Correspondence: ezrayosefantu@yahoo.com

${ }^{1}$ Faculty of Health Sciences, School of Pharmacy, Jimma University, 378 Jimma, Ethiopia

Full list of author information is available at the end of the article
}

men, women, and children await life-saving organ transplants [2]. Accor-ding to a survey In India every year about 5 lakh $(500,000)$ people die because of nonavailability of organs and 1.5 lakh $(150,000)$ people await a kidney transplant but only 5000 get among them [3]. Recently published report has found that approximately 3 million people in sub-Saharan Africa diagnosed with end-stage kidney disease (ESKD) die each year due to renal failure [4]. In Kenya, the kidney transplant queue

C C The Author(s). 2020 Open Access This article is licensed under a Creative Commons Attribution 4.0 International License, which permits use, sharing, adaptation, distribution and reproduction in any medium or format, as long as you give appropriate credit to the original author(s) and the source, provide a link to the Creative Commons licence, and indicate if changes were made. The images or other third party material in this article are included in the article's Creative Commons licence, unless indicated otherwise in a credit line to the material. If material is not included in the article's Creative Commons licence and your intended use is not permitted by statutory regulation or exceeds the permitted use, you will need to obtain permission directly from the copyright holder. To view a copy of this licence, visit http://creativecommons.org/licenses/by/4.0/ The Creative Commons Public Domain Dedication waiver (http://creativecommons.org/publicdomain/zero/1.0/) applies to the data made available in this article, unless otherwise stated in a credit line to the data. 
at Kenyatta National Hospital in Nairobi stretches all the way to 2018 , despite the hospital performing the procedure on a weekly basis [5]. In Ethiopia, between 130 and 150 corneas are collected yearly. However, there are more than 300,000 blind people waiting for corneal transplantation [6].

There are no sufficient facilities which provide maintenance and transplantation therapy for failed organs in Ethiopia. Currently there are only cornea and living related kidney transplant programs established in the nation's capital Addis Ababa [6]. Facilities which provide maintenance dialysis has been in existence in the country starting from 2001. Hemodialysis has become on hand in private institutions, mostly in Addis Ababa the capital city of the country, and more recently in a few other urban and semi-urban regions. Currently, there are 30 hemodialysis centers with a total of 186 hemodialysis chairs and approximately 800 patients on hemodialysis. Among patients on maintenance dialysis, only about one-third receives treatment $3 \times$ per year because the cost of hemodialysis is unaffordable for the majority of patients [7].

Organ transplantation is one of the great advances in modern medicine and is the best option for failed organ. Transplantation is defined as the transfer of human cells, tissues or organs from a donor to recipient with an aim of restoring normal physiology in the body [8]. In Ethiopia, up to 2018, 1336 corneal and 90 living donor kidney transplants have been performed. Currently the kidney transplant program accepts candidates only at the age of 14 and above $[7,9]$.

Some studies found out that the issue of organ donation is multifactorial. In developed countries relational ties, religious beliefs, cultural influences, family influences, body integrity, and previous interactions with the health-care system were reported as the potential factors for organ donation [10]. However, there are limited studies regarding organ donation and the factors that influence it in developing countries for instance, in Kenya there are peoples who believe a person's body should be intact when buried this belief and other sociocultural and legal factors hinder the harvest of organ from patients who have been medically declared to be in a "state of dying" [5].

Among 100,000 of people died each year are believed to be potential donors; however, only less than 200 actually become donors [11]. This indicates that a lot should be done on awareness creation towards organ donation. As a new approach in solving the organ shortage, it has been suggested that awareness about organ donation to be made a part of school education [12]. In Ethiopia we suggest to use religious leaders besides to incorporating the issue in school education, because Ethiopia is religious country. Our country has close ties with all three major Abrahamic religions, and it was the first in the region to officially adopt Christianity in the fourth century. Christians account for $63 \%$ of the country's population, with $43.5 \%$ belonging to the Ethiopian Orthodox Church, 18.5\% Protestant and 0.7\% Catholic. Ethiopia has the first Hijra in Islamic history and the oldest Muslim settlement on the continent. Muslims account for $34 \%$ of the population, traditional $2.7 \%$ and other $0.6 \%$ [13].

In Ethiopia there are no data on public perception of organ donation and transplantation Therefore, the present study was designed to assess the knowledge, attitude and willingness of organ donation among medical students. Medical students, as future doctors can take up the role of promoting organ donation by educating and motivating the public to initiate them donate their organs besides their voluntary organ donation. Therefore, assessing medical student's knowledge, attitude and willingness to donate organ is very important to decrease the shortage of organ in the future.

\section{Methods \\ Study setting and subjects}

A cross sectional study was carried out for 3 months from May to July 2019among under graduate medical students in Jimma University after obtaining Institutional Ethical Clearance from institutional review board (IRB) of Jimma University. The University is located in Jimma town which is $352 \mathrm{~km}$ from Addis Ababa, the capital city of Ethiopia. Jimma University is one of the most distinguished centers of excellence in medical education in the country.

\section{Sample size}

All medical students (from first to internship) registered in the year 2018/2019 were the source population. Based on their training background, medical students in Jimma University were divided into two groups: PRE-CLINICAL and CLINICAL. PRECLINICAL is subdivided in to two groups: Year I (PC-I) and Year II (PC-II) and CLINICAL in to three subgroups Year III(C-I), Year IV(C-II) and internship. The sample size was calculated by using simple proportion formula assuming a prevalence of $50 \%$ for knowledge, attitudes and willingness of organ donation, a $95 \%$ confidence interval and a sample error of $5 \%$. This was adjusted for $10 \%$ non-response rate; bringing the total sample size to 320 .There were about 1200 students studying in Jimma University medical school.

\section{Study tool}

The questionnaire was distributed to undergraduate medical students during lecture hours in the classroom and in ward during attachment. They were instructed not to discuss the questions among themselves. The importance of the study was explained and confidentiality 
regarding the participant response for the questions was ensured.

A 20-item self-administered questionnaire was developed. The first part of the questionnaire gathered the demographic details from the students, which included age, gender, year of study and religion. The second, third and fourth sections assessed the levels of knowledge (Q1-7), attitude (Q8-16) and willingness (Q17-20) to donate organ, respectively.

The students were grouped as those who do have adequate and inadequate knowledge based on their score.

Adequate knowledge is when 4-6 questions were answered correctly and inadequate when less than 4 questions answered correctly out of 6 knowledge questions.

Attitude was assessed by using 9 attitude statements and respondents were categorized as those who do have positive attitude and negative if they agree to 6-9 and less than 6 attitude statements respectively.

\section{Statistical analysis}

Data was entered to EPI data and exported to SPSS version 20 for analysis. Descriptive statistics like percentage and mean and standard deviation were used to present socio-demography, knowledge, attitude and willingness response of the participants. Multivariate analysis was used in order to relate those factors that gave a significant result: One way Multivariate analysis of variance (MANOVA) was used to see a significant relationship between one independent variable and dependent variables and two ways MANOVA was considered to know if there was an interaction between two independent variables on the dependent variables. One way Analysis of Variance (ANOVA) was used for comparing means of variables to know among which groups were the differences. Finally, Odds ratio analysis was used to find out variables which were related to a positive attitude towards organ donation.

\section{Result}

Out of 320 participants $57.8 \%$ were male. Mean $( \pm$ SD $=$ standard deviation) age of participants was $23.48 \pm$ 17.025 years. Majority of the participants were orthodox (49\%.7) and the least percentage being others constituting wakeefeta, apostolic, humanity, atheist and Seventh Day Adventist (SDA) (2.8\%) (Table 1).

96.9\% of the students had awareness about organ donation. Only $25 \%$ had knowledge that there was no age limit for organ donation (Table 2).

There was a statistically significant difference in level of knowledge between study groups as demonstrated by one-way $\operatorname{ANOVA}(\mathrm{F}(4,315)=7.6, p=0.001)$. Based on the post hoc test the significant difference was between PC-I and C-II $(p=0.001), \mathrm{PC}-\mathrm{I}$ and intern $(p=0.001), \mathrm{PC}-$ II and $\mathrm{C}-\mathrm{I}(P=0.022)$ and PC-II and intern $(p=0.010)$.
Table 1 Sociodemographic data of the participants

\begin{tabular}{ll}
\hline Sociodemographic variables & $N=320(\%)$ \\
\hline Age & $33(10.3)$ \\
$18-19$ & $121(37.8)$ \\
$20-21$ & $87(27.2)$ \\
$22-23$ & $66(20.6)$ \\
$24-25$ & $13(4.1)$ \\
$>25$ & \\
Mean age \pm SD $=23.48 \pm 17.025$ & \\
Sex & \\
Male & $185(57.8)$ \\
Female & $135(42.2)$ \\
Religion & \\
Orthodox & $159(49.7)$ \\
Protestant & $109(34.1)$ \\
Muslim & $43(13.4)$ \\
Others & $9(2.8)$ \\
Year of study & \\
PC-I & $46(14.4)$ \\
PC-II & $60(18.8)$ \\
C-I & $66(20.6)$ \\
C-II & $87(27.2)$ \\
Internship & $61(19.1)$ \\
\hline
\end{tabular}

The mean for PC-I, PC-II, C-I, C-II and intern is 1.37, $1.27,1.20,1.08$ and 1.05 respectively. Therefore, $\mathrm{PC}=\mathrm{I}$ had significantly higher level of knowledge when compared to the rest year of study (Table 3).

$74.1 \%$ of the participants agreed to support family members if they wish to become an organ donor. Majority of the study subjects (91.9\%) felt that awareness

Table 2 Knowledge of medical students regarding organ donation $(n=320)$

\begin{tabular}{lll}
\hline S. no & Question & $\begin{array}{l}\text { No of students } \\
\text { answered correctly } \\
(\%)\end{array}$ \\
\hline $1 \quad$ & $\begin{array}{l}\text { Have you ever heard about Organ } \\
\text { Donation? (Yes/No) }\end{array}$ & $310(96.9)$ \\
2 & The term 'Organ Donation' means? & $237(74.1)^{\mathrm{a}}$ \\
3 & $\begin{array}{l}\text { Do you know the meaning of brain } \\
\text { death? (Yes/No) }\end{array}$ & $282(88.1)$ \\
5 & $\begin{array}{l}\text { Which organs can be donated? } \\
\text { Is there age limit for donating organs? } \\
\text { (Yes/No) }\end{array}$ & $206(64.4)^{b}$ \\
6 & $\begin{array}{l}\text { All religions support organ donation } \\
\text { (True/False) }\end{array}$ & $274(85.6)$ \\
\hline
\end{tabular}

a Medical students who had chosen the correct definition of 'Organ Donation'; ${ }^{b}$ Medical students who had correctly identified all the given organs that can be donated 
Table 3 Comparison of level of knowledge of study participants based year of study

\begin{tabular}{lll}
\hline Year of study & Year of study & $P$ \\
\hline PC-I & PC-II & .606 \\
& C-I & .104 \\
& C-II & $.001^{*}$ \\
& Intern & $.001^{*}$ \\
PC-II & C-I & .823 \\
& C-II & $.022^{*}$ \\
& Intern & $.010^{*}$ \\
C-I & C-II & .293 \\
& Intern & .156 \\
C-II & Intern & .986 \\
\hline *The mean difference is significant at 0.05 level
\end{tabular}

about organ donation should be made a part of school education (Table 4).

According to our finding, males were 1.156 (Odds Ratio = 1.156) times likely to have positive attitude towards to organ donation as compared to female. Students who had an awareness about organ donation were 2.602 (Odds Ratio $=2.602$ ) times likely to have positive attitude towards to organ donation as compared to those who were unaware. The other variables which were related to a positive attitude towards organ donation were: not having a belief on the importance of burying intact body (Odds Ratio $=5.434$ ); knowing definition of brain death (Odds Ratio = 1.257); not having a belief that there is a danger of misuse, abuse or misappropriation of donated organ (Odds Ratio $=2.777$ ); willingness to donate blood (Odds Ratio $=4.813$ ); and willingness to donate organ (Odds Ratio $=19.424$ ).

$58.1 \%$ of the study participants were willing to donate their organs and allow organ donation after the death of a family member. Majority of the study subjects $(88.4 \%)$ did not like to take money for organ donation. $90.3 \%$ of the study subjects were willing to donate blood and $58.1 \%$ were willing to donate their organ (Table 5) (Fig. 1).
There were an association between willingness and attitude. Willingness to donate organ was significantly higher among those who do have positive attitude $(88.2 \%)$ as compared to those with negative attitude (11.8\%) (Table 6).

There was a statistically significant difference on belief of burying intact body between religions as demonstrated by one-way $\operatorname{ANOVA}(\mathrm{F}(3,316)=4.5, p=.004)$. Based on the post hoc test the significant difference was between Protestant and Muslim ( $p=.007)$. The mean for protestant is 1.83 and Muslim 1.56.Therefore, Protestant had significantly higher belief on the importance of burying intact body when compared to Muslim (Table 7).

There was a statistically significant difference between males and females when knowledge questions considered jointly Wilk's $\Lambda=.96, \mathrm{~F}(6,312)=2.247, P=0.039$, multivariate $\eta^{2}=0.041$ and attitude statements consider jointly Wilk's $\Lambda=.94$, F $(9,310)=2.301, P=0.016$, multivariate $\eta^{2}=0.063$

When year of study is considered, there was a statistically significant difference among year of studies when knowledge questions considered jointly Wilk's $\Lambda=.75$, F $(25,079)=3.966, \quad P<0.001, \quad$ multivariate $\eta^{2}=.071$, attitude statements considered jointly Wilk's $\Lambda=.77$, F $(37,152)=.766, P<0.001$, multivariate $\eta^{2}=.065$ and willingness questions considered jointly Wilk's $\Lambda=.93$, $\mathrm{F}(12,828)=2.072, P=0.017$, multivariate $\eta^{2}=.026$.

Two way MANOVA was considered to know if there was an interaction between two independent variables on the dependent variables. There was a statistically significant interaction effect between gender and year of study on the combined knowledge questions (dependent variables) $\mathrm{F}(25,062)=1.755, P=0.014$, Wilk's $\Lambda=.033$.

\section{Discussion}

\section{Knowledge of the participant}

Organ failure and shortage of donated organs are global problem. Among 100,000 of people died each year are believed to be potential donors; however, only less than 200 actually become donors [9]. The widespread shortage of

Table 4 Attitude of medical students regarding organ donation $(n=320)$

\begin{tabular}{llll}
\hline S. No & Attitude statements & Subjects who replied yes(\%) \\
\hline 1 & Would you like to donate your organs? & & \\
2 & Do you feel comfortable to think or talk about organ donation? & 2167.5) \\
3 & Would you like to motivate others to donate organs? & 256 (80) \\
4 & Do you support your family members if they wish to become an organ donor? & 251 (78.4) \\
5 & Do you think awareness about organ donation should be made a part of school education & 237 (74.1) \\
6 & It is important for a person's body to have all of its parts when buried & 294 (91.9) \\
7 & Would you like to donate your organ to anybody? & 177 (24.1) \\
9 & Do you think donating an organ can cause any harmful effects / complication to you? & 186 (58.1)
\end{tabular}


Table 5 Willingness among medical interns regarding organ donation $(n=160)$

\begin{tabular}{lll}
\hline S. no & Questions & $\begin{array}{l}\text { Students who } \\
\text { replied yes (\%) }\end{array}$ \\
\hline 1 & Are you willing to donate blood? & $289(90.3)$ \\
2 & Are you willing to donate your organ? & $186(58.1)$ \\
3 & $\begin{array}{l}\text { Are you willing to allow organ donation } \\
\text { after the death of a family member? }\end{array}$ & $186(58.1)$ \\
4 & $\begin{array}{l}\text { Would you like to take money for organ } \\
\text { donation? }\end{array}$ & $37(11.6)$ \\
\hline
\end{tabular}

donated organs indicates that there is low donor rate worldwide; In Ethiopia there is no data on rate of organ donation. In 2017 Spain had the highest donor rate in the world at 46.9 per million people, followed by Portugal (34.0 per million), Belgium (33.6 per million), Croatia (33.0 per million) and the US (32.0 per million) [14]. Donated organs are the major pre-requisite for consistency of organ transplantation program; one of the solutions to increase organ supply is to assess public knowledge, attitude and willingness towards organ donation and taking an action based on the data. In our country there is no study done on people's perception towards organ donation this background pledges us to conduct this study.

In our study $96.9 \%$ of the participants heard about organ donation which is similar to study done by Annadurai et al and Jothula et al. $[15,16]$ both reported that $100 \%$ of the participants were aware about organ donation.74.1\% of the participants were aware about the meaning of organ donation which is relatively higher than the study done by Annadurai et al. [15]. In the present study, level of knowledge was significantly higher among $\mathrm{PC}=\mathrm{I}$ (year I) students as compared to the other year of study this finding was similar to study done among undergraduate dental students of Panineeya Institute of Dental Sciences and Hospital, which showed higher average knowledge among first-year students [17]. In this study, only $82.5 \%$ of medical students had adequate knowledge about organ donation which is relatively higher than the study done on final semester medical students by Karini et al. which showed that only $56 \%$ of them were having adequate knowledge [18].

In the present study the main sources of information about organ donation was found to be internet (61\%) and television (50\%).This was similar to study conducted in USA and Australia $[19,20]$. However; Similar findings were observed by Sindhu et al. and Jothula KY et al. [16, 21]. The third source of information about organ donation in our study are health care providers (45\%) which is relatively higher than the study done by Annadurai et al. [15] which reported $34.1 \%$. this finding showed that health care providers are playing undeniable role in creating awareness towards organ donation in Ethiopia.

206(64.4\%) of our study participants had identified all the organs that can be donated. This finding was higher than the study done by Annadurai et al. [15] and Karini et al. [18] which reported 16.1 and $26 \%$ respectively. In the present study $80(25 \%)$ of the students knew that there is no age limit for organ donation which is approximate to Sucharitha et al. and lower than Jothula KY et al. [16, 22].

\section{Attitude of medical students regarding organ donation}

$201(62.8 \%)$ of our study subjects have a positive attitude towards organ donation which is lower than the study in Spain and India which found 80 and $71.3 \%$ respectively $[23,24] .91 .9 \%$ of this study subjects, felt that awareness about organ donation should be included in school

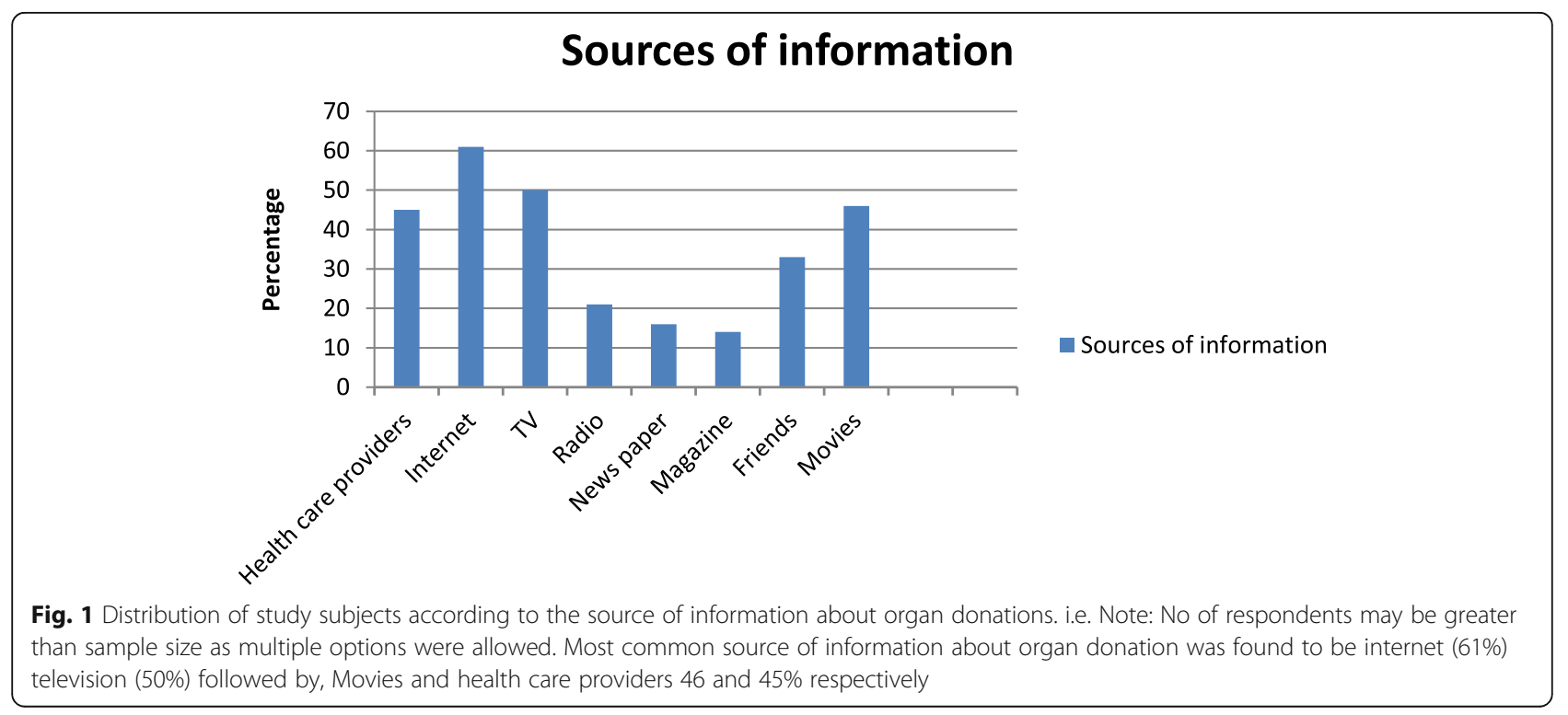


Table 6 Association of attitude and willingness to donate organ

\begin{tabular}{llll}
\hline $\begin{array}{l}\text { Are you willing } \\
\text { to donate your } \\
\text { organ? }\end{array}$ & Attitude & Total \\
\cline { 2 - 3 } & Positive(\%) & Negative(\%) & \\
\hline Yes & $164(88.2)$ & $22(11.8)$ & $186(100)$ \\
No & $37(27.6)$ & $97(72.4)$ & $134(100)$ \\
Total & $201(62.8)$ & $119(37.2 \%)$ & $320(100)$ \\
\hline$x^{2}=122.3 ; \mathrm{df}=1 ; P<0.001$ & &
\end{tabular}

curriculum which is similar to Adithyan et al. reported that $91.2 \%$ of the subjects felt the need for revision of medical curriculum on organ donation [25] Our study found out that $251(78.4 \%)$ of the study subjects would like to motivate others for organ donation which is lower than to the Vinay et al [26].

$77(24.1 \%)$ of our study subjects belief that person's body should be intact when buried A study in USA reported that $8 \%$ of participants strongly agree and $11.7 \%$ agree to this statement which is almost similar to our finding [19]. In our study being of the male sex (Odds Ratio $=1.156$ ) was related to a favorable attitude towards to organ donation; in contrast, a study done in Spain reported that being of females sex (Odds Ratio $=1.739$ ) was related to a favorable attitude [23]. In our study not having a belief on the importance of burying intact body (Odds Ratio $=$ Ratio $=5.434)$ was one of the variables which affect positive attitude towards to organ donation which was similar to a study in USA [19]. A study done in Spain reported being a blood donor $(\mathrm{OR}=2.824)$ as a variable related to a positive attitude towards to organ donation similarly in our study we found out willingness to donate blood (Odds Ratio $=4.813$ ) as a variable to a favorable attitude.

\section{Willingness of medical students to donate organ}

In this study $186(58.1 \%)$ of the study participants were willing to donate their organ which is similar to a study done in USA [20] and lower than Payghan et al. and Vinay et al revealed that almost $90 \%$ of study participants were willing to donate their organs [26, 27]. The present study found out that there is a significant association between attitude regarding organ donation and

Table 7 Comparison of belief of participants on the importance of burying intact body based on religion

\begin{tabular}{lll}
\hline Religion of the subject & Religion of the subject & $P$ \\
\hline Orthodox & Protestant & .677 \\
& Muslim & .051 \\
& Other & .853 \\
Protestant & Muslim & $.007^{*}$ \\
& Other & .980 \\
Muslim & Other & .207 \\
\hline
\end{tabular}

*The mean difference is significant at 0.05 level willingness to donate organs which is different from the finding by Ali et al. and by Dasgupta et al. [28, 29] which reported that there was a significant association between attitude and knowledge acquired. Though taking money for organ donation is unethical $11.6 \%$ of our study participants would like to take money for organ donation which was higher than study by Jothula KY et al. [16].

\section{Conclusion}

Though most of the students had adequate knowledge, still gaps exist in their attitude and willingness. This implies the need for an intensified and sustained education to raise attitude and willingness of the students towards organ donation.

\section{Recommendations}

Most of the students (91.9\%) felt that awareness about organ donation should be made a part of school education; until it included in school curriculum, we recommend the students to acquire an adequate knowledge by themselves; In our study the most common source of information about organ donation was internet; so, they can browse more to acquire additional knowledge and make informed decision.

\section{Abbreviations \\ ANOVA: Analysis of variance; C-I: Clinical-I; C-II: Clinical-II; ESKD: End-stage kidney disease; IRB: Institutional Review Board; JUMC: Jimma University Medical College; MANOVA: Multivariate analysis of variance; PC-I: Pre-clinical-I; PC-II: Pre-clinical-II; SDA: Seventh Day Adventist; SPSS: Statistical Package for Social Sciences; USA: United States of America}

\section{Acknowledgements}

Not applicable.

\section{Authors' contributions}

$F K D, E M B, K K G, A D W, F G F, A W G, B E T$ involved in the data collection. FKD analyze the data and FKD and EMB prepared the manuscript. All authors read and approved the final manuscript.

\section{Funding}

The study was funded with the support of Jimma University; Faculty of Health Science. The funding body has no role in the design of the study and collection, analysis, and interpretation of data and in writing the manuscript.

\section{Availability of data and materials}

The datasets used and/or analysed during the current study are available from the corresponding author on reasonable request.

Ethics approval and consent to participate

The study protocol was approved by the institutional review board (IRB) of Jimma University, College of Health Sciences and ethical clearance was obtained with the Reference Number IHRPGD/3019/2019. Permission of data collection was granted with formal letter from chief executive director of Jimma University Medical College (JUMC). The purpose and protocol of this study was explained, participants signed informed written consent.

Consent for publication

Not applicable.

Competing interests

The authors declare that they have no competing interests. 


\section{Author details}

'Faculty of Health Sciences, School of Pharmacy, Jimma University, 378 Jimma, Ethiopia. Facility of Medicine, Jimma University, 378 Jimma, Ethiopia. ${ }^{3}$ Faculty of Health Sciences, School of Midwifery and Nursing, Jimma University, 378 Jimma, Ethiopia.

Received: 19 September 2019 Accepted: 17 May 2020

Published online: 27 May 2020

\section{References}

1. Wakefield MA, Loken B, Hornik RC. Use of mass media campaigns to change health behaviour. Lancet. 2010;376(9748):1261-71.

2. Organ Donation Facts \& Info _ Organ Transplants _ Cleveland Clinic www. unos.org , Nov. 1, 2016. Accessed 26 Jan 2020.

3. National Health Portal. "Organ donation day". Available at http://www.nhp. gov.in/organdonation-day_pg. Accessed 18 Feb 2018.

4. Ashuntantang G, Osafo C, Olowu WA, et al. Outcomes in adults and children with end-stage kidney disease requiring dialysis in sub-Saharan Africa: a systematic review. Lancet Glob Health. 2017;5:e408-17.

5. Organ failure: patients in East Africa wait endlessly for donors. Science \& Health https://www.theeastafrican.co.ke. Accessed 26 Aug 2019

6. Rao GN, Gopinathan U. Eye banking: an introduction. Community Eye Health. 2009;22(71):46-7.

7. Ahmed, et al. Organ transplantation in Ethiopia. 2019:103(3):449-51.

8. World Health Organisation (WHO). Global glossary of terms and definitions on donation and transplantation, vol. 14. Geneva; 2009.

9. 13. Eye Bank of Ethiopia celebrates $15^{\text {th }}$ anniversary June 28,2018 by New Business Ethiopia. http://newbusinessethiopia.com/health/eye-bank-ofethiopia-celebrates-15th-anniversary/.

10. Irving MJ, Tong A, Jan S, Cass A, Rose J, Chadban S, et al. Factors that influence the decision to be an organ donor: a systematic review of the qualitative literature. Nephrol Dial Transplant. 2012;27:2526-33.

11. Sahi M. Myths and misconceptions and reality on organ donation. Transplantation Research. https://www.mohanfoundation.org/organdonation-transplant-resources/Myths-Misconceptions-and-the-Reality-ofOrgan-Donation.asp.

12. Burra $\mathrm{P}$, De Bona M, Canova D, et al. Changing attitude to organ donation and transplantation in university students during the years of medical school in Italy. Transplant Proc. 2005;37:547-50.

13. Ethiopia PEOPLE 2019, CIA World Fact book Theodora.com https://theodora. com/wfbcurrent/ethiopia/ethiopia_people.html.

14. Newsletter 2018 (PDF). International registry in organ donation and transplantation. 2018. Retrieved December 30, 2018.

15. Annadurai K, Mani K, Ramasamy J. A study on knowledge, attitude and practices about organ donation among college students in Chennai, Tamil Nadu -2012. Prog Health Sci. 2013:3:2 KAP on organ donation.

16. Jothula KY, Sreeharshika D. Study to assess knowledge, attitude and practice regarding organ donation among interns of a medical college in Telangana, India. Int J Community Med Public Health. 2018;5:1339-45.

17. Chakradhar K, Doshi D, Srikanth Reddy B, et al. Knowledge, attitude and practice regarding organ donation among Indian dental students. Int J Organ Transplant Med. 2016;7(1):28-35.

18. Karini D, Sunitha S, Devi Madhavi B. Perceptions of medical students in a government medical college towards organ donation. J Evid Based Med Healthc. 2015;2(44):7998-8005

19. U.S. Department of Health and Human Services, Health Resources and Services Administration, Healthcare Systems Bureau, 2012 National Survey of Organ Donation Attitudes and Behaviors. Rockville, Maryland: U.S. Department of Health and Human Services; 2013.

20. Hyde MK, Chambers SK. Information sources, donation knowledge, and attitudes toward transplant recipients in Australia. Prog Transplant. 2014;24: 169-77.

21. Sindhu A, Ramakrishnan TS, Khera A, Singh G. A study to assess the knowledge of medical students regarding organ donation in a selected college of Western Maharashtra. Med J DY Patil Univ. 2017;10:349-53.

22. Agarwal S. Are medical students having enough knowledge about organ donation. IOSR J Dental Med Sci. 2015;14(7):29-34

23. Ríos A, López-Navas A, López-López A, Gómez FJ, Iriarte J, Herruzo R, Blanco G, Llorca FJ, Asunsolo A, Sánchez P, Gutiérrez PR, Fernández A, de Jesús MT, MartínezAlarcón L, Lana A, Fuentes L, Hernández JR, Virseda J, Yelamos J, Bondía JA, Hernández AM, Ayala MA, Ramírez P, Parrilla P. A multicentre and stratified study of the attitude of medical students towards organ donation in Spain. Ethn Health. 2019;24(4):443-61. https://doi.org/10.1080/13557858. 2017.1346183

24. Bathija GV, Ananthesh BG, Bant DD. Study to assess knowledge and attitude towards organ donation among interns and post graduates of a medical college in Karnataka, India. Natl J Community Med. 2017;8(5):236-40.

25. Adithyan GS, Mariappan M, Nayana KB. A study on knowledge and attitude about organ donation among medical students in Kerala. Indian J Transplant. 2017;11:133-7.

26. Vinay KV, Beena N, Sachin KS, Praveen S. Changes in knowledge and attitude among medical students towards organ donation and transplantation. Int J Anat Res. 2016;4(3):2873-7.

27. Payghan BS, Kadam SS, Furmeen S. Organ donation: awareness and perception among medical students. J Pharm Sci Innov. 2014;3(4):379-81.

28. Ali NF, Qureshi A, Jilani BN, Zehra N. Knowledge and ethical perception regarding organ donation among medical students. BMC Med Ethics. 2013;14:38.

29. Dasgupta A, Shahbabu B, Sarkar K, Sarkar I, Das S, Das MK. Perception of organ donation among adults: a community based study in an urban. Sch J App Med Sci. 2014;2(6A):2016-2021.

\section{Publisher's Note}

Springer Nature remains neutral with regard to jurisdictional claims in published maps and institutional affiliations.

Ready to submit your research? Choose BMC and benefit from:

- fast, convenient online submission

- thorough peer review by experienced researchers in your field

- rapid publication on acceptance

- support for research data, including large and complex data types

- gold Open Access which fosters wider collaboration and increased citations

- maximum visibility for your research: over $100 \mathrm{M}$ website views per year

At $\mathrm{BMC}$, research is always in progress.

Learn more biomedcentral.com/submissions 